\title{
GREEN COMPETITIVENESS: UKRAINE'S BUSINESS SECTOR IN THE WORLDWIDE TRENDS FRAMEWORK
}

\author{
Olena Chygryn; Oleksii Lyulyov; Tetyana Pimonenko; \\ Svitlana Kostornova
}

\author{
Sumy State University, Sumy, Ukraine
}

\begin{abstract}
Summary. The paper deals with the analysis of measurement approaches for stable competitiveness. The authors substantiate that promotion the stable competitiveness requires the creation of modern theoretical approaches for its measurement and understanding the relevant trends in the national business sector. The analysis results prove that green competitiveness is the part of national economy competitiveness and modern trends indicate that the European countries create new market opportunities for green growth promotion and ecological competitiveness increase. The objective of the paper is to investigate the measurement system for the global stable competitiveness and to analyze the Ukraine internal peculiarities in comparison with the post-Soviet and European countries. The analysis results prove that today's worldwide trends and tendencies of the countries green competitiveness measurement are described in the approach implemented by the Global Stable Competitiveness Index. The given methodology includes three basic aspects of stable development: economy, environment and society and defines the investigated areas within the framework of five basic fields: natural capital; social capital; resource management; intellectual capital and innovations; managerial efficiency. TOP-20 countries representation according to the Global Stable Competitiveness Index is considered, the leading developed high-income countries are determined and analyzed in this investigation. Ukraine's position among the European and Post-Soviet countries is shown in this papers. It ranks the 74th place among 180 countries and its score level is 44.7. The authors estimate the prospects for the Ukraine stable competitiveness increase within the framework of its five main determinants.
\end{abstract}

Key words: stable development, ecological competitiveness, index, estimation, capital, innovation, efficiency.

\section{УДК 339.138:502.3}

\section{ЗЕЛЕНА КОНКУРЕНТОСПРОМОЖНІСТЬ БІЗНЕС-СЕКТОРА УКРАЇНИ В РАМКАХ ГЛОБАЛЬНИХ ТЕНДЕНЦЙ}

\section{Олена Чигрин; Олексій Люльов; Тетяна Пімоненко; Світлана Косторнова}

\author{
Сумський державний університет, Суми, Украӥна
}

\begin{abstract}
Резюме. Розглядається аналіз підходів до вимірювання стійкоӥ конкурентоспроможності. Обтрунтовано, щзо сприяння стійкій конкурентоспроможності потребує створення сучасних теоретичних підходів для ї̈ вимірювання та розуміння відповідних тенденцій у вітчизняному бізнессекторі. Результати аналізу показали, щзо зелена конкурентоспроможність $\epsilon$ частиною конкурентоспроможності національних економік, а сучасні тенденції свідчать, щзо європейські країни створюють нові ринкові можливості для просування зеленого зростання та посилення екологічної конкурентоспроможності. Метою статті було дослідити систему вимірювання глобальної стійкої конкурентоспроможності та проаналізувати внутрішні особливості Украӥни порівняно з краӥнами пострадянського простору та європейськими крайнами. Результати аналізу довели, щзо сучасні глобальні тенденції вимірювання конкурентоспроможності країн, описані в підході, реалізованому за допомогою
\end{abstract}


Глобального індексу стійкої конкурентоспроможності. Дана методологія включає три основні аспекти сталого розвитку: економіку, довкілля та суспільство і визначає напрями, щуо досліджуються в рамках п'яти основних сфер: природного капіталу; соціального капіталу; управління ресурсами; інтелектуального капіталу й інновацій; ефективності управління. У изьому дослідженні було розглянуто представництво ТОП-20 краӥн відповідно до Глобального індексу стійкої конкурентоспроможності, визначено та проаналізовано провідні розвинені країни з високим рівнем доходу. Показано місие Украӥни серед краӥн Свропи та пострадянських краӥн. Вона займає 74 місие серед 180 краӥн, а рівень балів - 44,7. Автори оцінили перспективи підвищення стійкої конкурентоспроможності Украйни в рамках $n$ 'яти основних ї̈ детермінант.

Ключові слова: стійкий розвиток, екологічна конкурентоспроможність, індекс, оцінювання, капітал, інновації, ефективністю.

Introduction. The development of green competitiveness requires the creation of modern theoretical approaches for its measurement for understanding the relevant tendencies in the Ukraine business sector. The most governments increasingly put sustainable development at the center of discussions over the economic growth and development of business sector. The green policy has to create the new jobs, new opportunities and technologies by increasing the competitiveness of national industry. So, the European countries create the new market opportunities for establishing the preconditions for green growth policies and strengthening the green competitiveness.

The objective of the article is to investigate the system of measurement the global stable competitiveness and to analyze the Ukraine national features in comparison with the postSoviet and European countries.

Literature review. The scientific literature which was analyzed showed that there are no approaches to determining green competitiveness and the key determinant of their defining.

The authors Hidalgo et al. [1], Hausmann etc. [2] suggest that green competitiveness is most likely to be derived from existing comparative advantages, skills and production patterns. The paper by Fankhauser [3] therefore, describes the existing capabilities as a key indicator of future comparative advantage in the green economy. For exploring the green performance and competitiveness the study provided by Sang-Bing Tsai [4] integrated simultaneous importance performance analysis and decision-making approaches. The scientist Zhang [5] emphasizes the main steps of estimation the green development competitiveness and shows the trends it's growing which strongly connected with the resource conservation and pollution reduction. Chengs' in his paper [6] emphasizes on balanced development of the economy, society, and the environment, which are the important issue for enhancing regional green competitiveness. The authors proposed a model to measuring the coupling coordination degree of green competitiveness from the different determinants. The domestic authors emphasize that green business is stimulate developing and promotion of the green competitiveness $[7,8]$.

The main part. The green competitiveness could be analyzed for the different levels of economy. Today the global trends and tendencies of the countries green competitiveness is described in the approach realized by the Global Sustainable Competitiveness Index. The Global Sustainable Competitiveness Index (GSCI) [9] estimates the total countries competitiveness with the interconnection of the stable development indicators. Such global index includes only quantitative indicators for excluding any subjectivity in the measurement.

The used methodology integrates three basic dimensions of stable development: economy, environment and society. Defined areas are investigated in the frame of the five basic fields: natural capital; social capital; resource management; intellectual capital; managerial efficiency.

The first field «natural capital» analyzes the natural environment of the country, the level of pollution, the availability of resources, the level of those resources exhaustion. 
The second field «social capital» estimates the population health, security level in the society, freedom, equality and life satisfaction within the country.

The third field «resource management» measures the efficiency of using available resources.

The fourth field «intellectual capital» investigates the capability to generate wealth and jobs through innovation and value-added industries in the globalized markets.

The managerial efficiency measures through salts of core state areas and investments infrastructure, market and employment structure, the provision of a framework for sustained and sustainable wealth generation.

We analyzed the TOP-20 countries representation according to the Global Stable Competitiveness Index (figure 1).

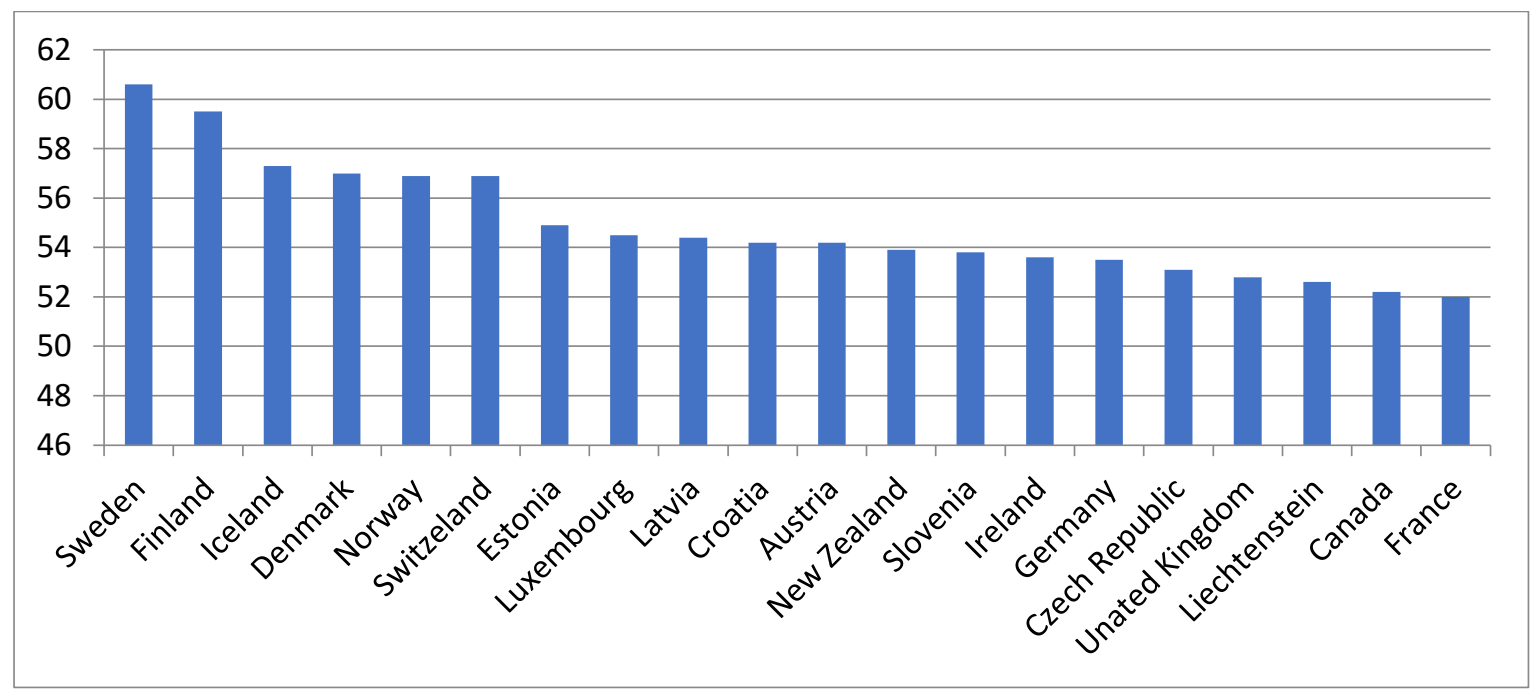

Figure 1. TOP-20 countries in the Global Stable Competitiveness Index

Source: developed by the authors on the basis of Global Stable Competitiveness Index, (2019).

Traditionally the leading nations on the stable competitiveness ranking are mostly developed high-income countries. As a result, it determines the strong correlation between Stable Competitiveness score and GDP per capita and demonstrates equality between income level and sustainability.

So, the represented structure of the countries shows that the Scandinavia and Northern Europe are on Top of the list. Top 5 spots are presented by Sweden, which is traditionally leading. Top 20 are presented by European countries, including the Baltic states. Of the top list of the green competitive countries only two are not European. That are New Zealand on the 12th place, and Canada on the 19th place. Moreover, the World's largest economy USA is on the 34th place.

At the same time, such countries as Sadia Arabia, Kuwait are the exceptions because they are ranked significantly below despite the high level of GDP. This indicates that the there is the correlation between stable competitiveness to income levels. 


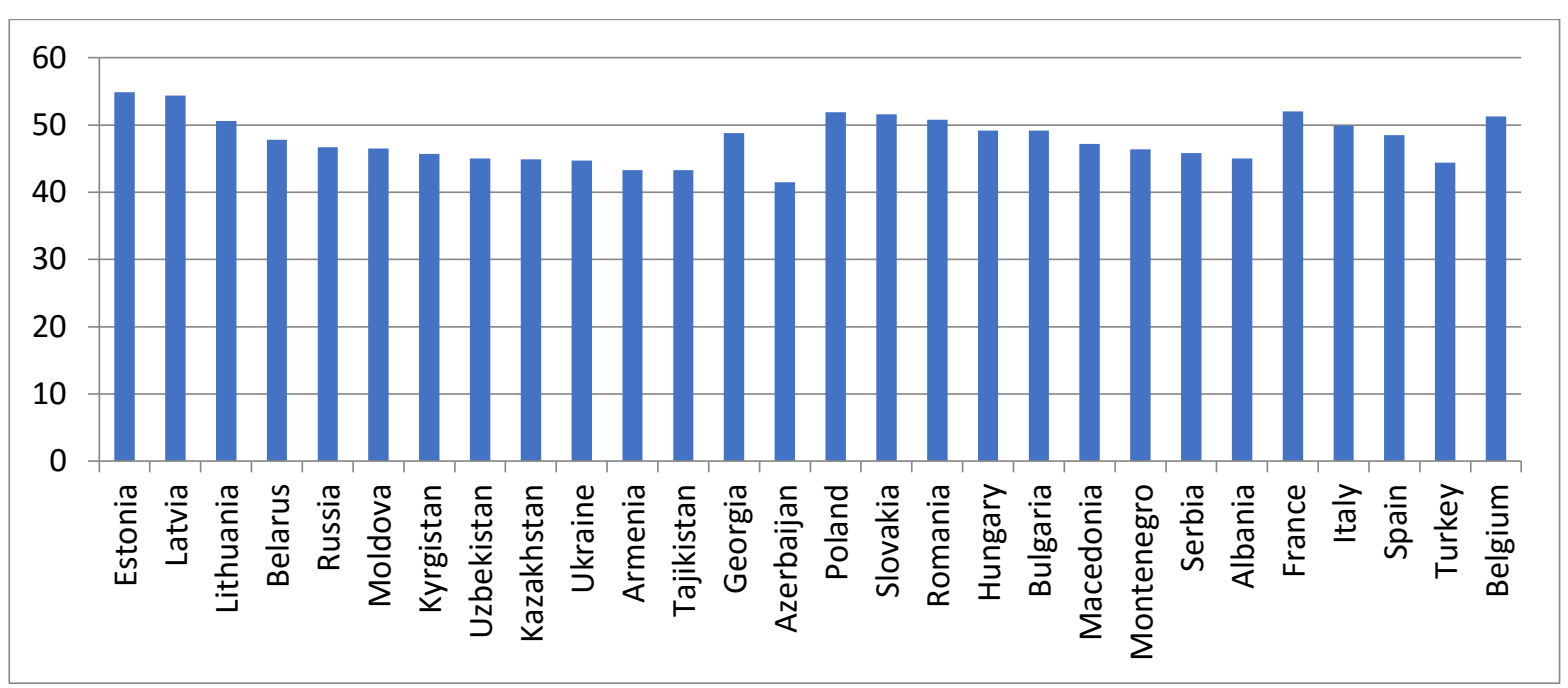

Figure 2. Ukraine rating in the Global Stable Competitiveness Index

Source: developed by the authors on the basis of Global Stable Competitiveness Index, (2019).

Figure 2 shows the position of Ukraine amongst the European and post-Soviet countries. So, Ukraine ranks the 74th place among 180 countries and the score level is 44.7. In comparison with the best rank Sweden which has 60.6 score and the average score 47.4 (Figure 3 ). It should be noted that the influence of stable competitiveness on GDP is prolonged in time. That is why it is quite important to provide the economic and managerial policy decisions according to the promotion of green competitiveness results.

The main fields of the global stable competitiveness index have the subdivided structure. So, it is quite important to understand which basic components create such index and determine the green competitiveness level.

The natural capital indicators consist from the five groups, which contain the next subgroups of indicators:

- agriculture, determined by the available land, yield efficiency, level of land degradation and desertification;

- biodiversity, which include information about forests, bioresources and biodiversity pressure;

- water resources: renewable and non renewable freshwater, agriculture water use;

- resources: energy and mineral resources, level of resource depletion.

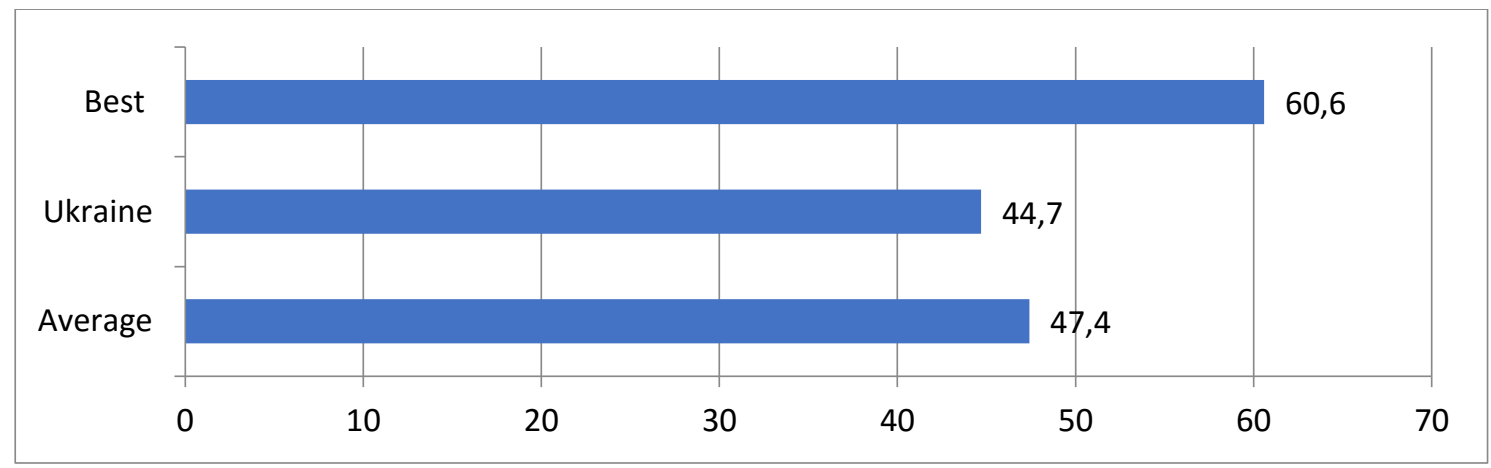

Figure 3. Ukraine ranking in the global Stable competitiveness rating

Source: developed by the authors on the basis of Global Stable Competitiveness Index, (2019). 
The second index associated with the managerial efficiency encompasses the next aspects connected with the strategic direction of government development: public infrastructure, business regulation system, sensibility to volatility, government cohesion. Such index includes the next sub indexes:

- government cohesion: public services, educational, budget, military spending;

- infrastructure: investments, transport system;

- business environment: creating business condition, business registration, sector developments;

- corruption: corruption index, bribery prevalence, red tape;

- financial stability: austerity, exposure to financial shocks, financial regulation.

The third index linked with the intellectual capital and innovation contains the sub indexes, which describe the next areas:

- education: school enrollment, school performance and infrastructure;

indicators;

- research and development: capital allocation, tertiary education, performance trademarks.

- new business opportunities: new business registration, high-tech manufacturing,

The fourth indicator evaluates the country's ability to support sustain economic growth in the form of rising prices in the global commodity markets. The resource intensity is measured by the next sub indexes, which determine the efficiency of the resource management system. The main investigating objects are:

- energy: fossil fuel, electricity, renewables;

- $\quad$ water: water per capita, water withdrawals rate, water productivity;

- raw materials: resources per capita, resources per GDP, resource balance.

The fifth group of the Global Stable Competitiveness Indicator selected to measure the social cohesion, which contain the sub indicators for estimating:

- health: health care availability, child mortality, family planning;

- equality: income equality, resource equality, gender equality;

- crime: theft, violent crime, prison population;

- freedom: press freedom, human rights, violent conflicts;

- $\quad$ satisfaction: individual happiness, suicide rate, public service satisfaction.

Figure 4 represents the stable competitiveness index for Ukraine.

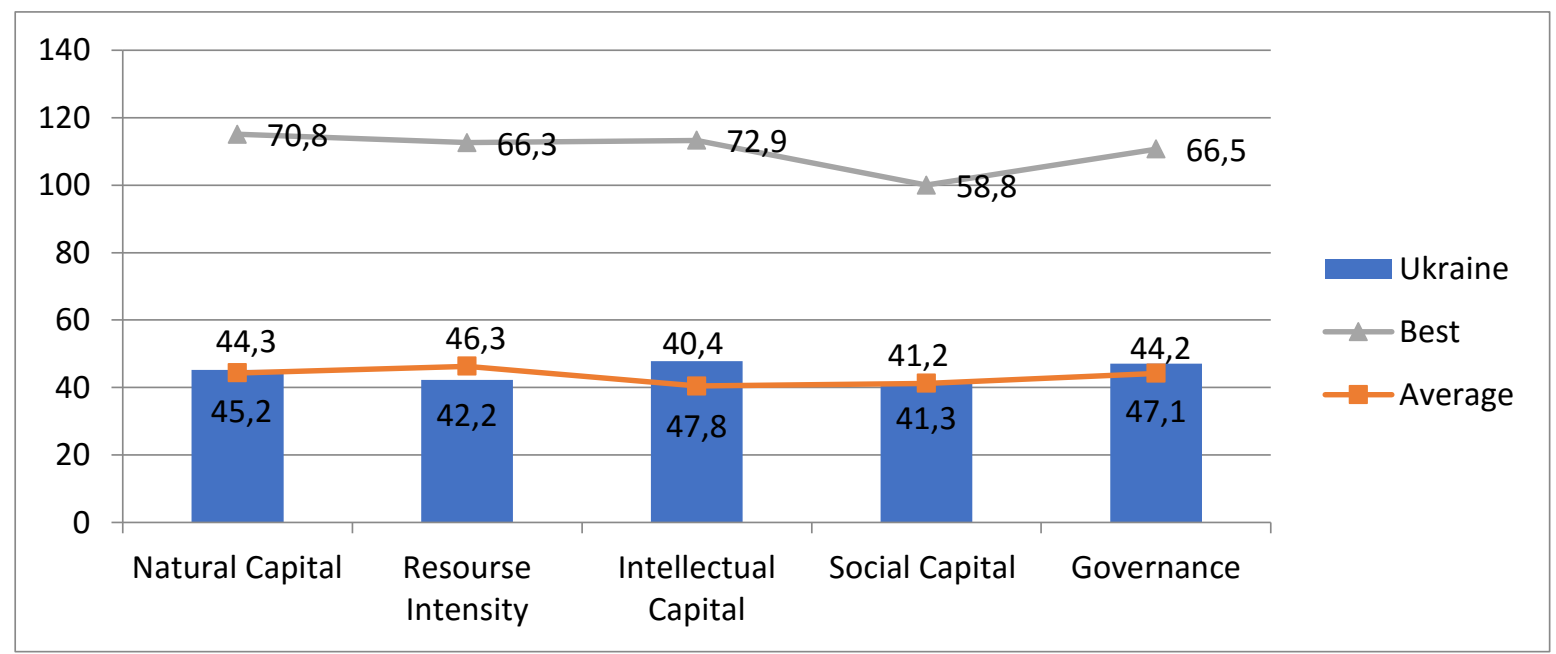

Figure 4. Ukraine in the global stable competitiveness rating

Source: developed by the authors on the basis of Global Stable Competitiveness Index, (2019). 
The diagrams show the Ukraine's level linking with the best and average results. So, in the frame of the natural capital competitiveness score Ukraine has 80 rank among 180 countries and the index score on the level 45.2. Such indicator is higher, then the average level (44.3) and practically two times lower than the best result (70.8).

The resource intensity of the Ukrainian entrepreneurship sector is lower than the average level and 36\% lower than the best Kenya's (66.3) result.

The next part of the Global Stable Competitiveness Index - Intellectual Capital is higher than the average score by $15 \%$. In that frame Ukraine represents 35 rank among 180 countries.

In the frame of social capital competitiveness score Ukraine has 87 score and 41.3 rank. That is on the average level and lower than the best result by $30 \%$.

The managerial efficiency competitiveness sub index for Ukraine is equal 47.1 score, that is lower than the average result (44.2) and retard from the best result by $20 \%$.

Accordingly, to the carried out analyses Ukraine's national economy could not be characterized as stable and competitive economy which is determined by the high efficiency. The national system hasn't the relevant approaches and policies that enable and foster efficiency and green competitiveness.

It is necessary to create the preconditions for increasing the Ukraine stable competitiveness. In the framework of five main fields of the green competitiveness $[10,11]$ we propose the main spheres where the basic improvements should be provided.

1. Natural capital management:

- $\quad$ creating the relevant legislation for the protection of natural biodiversity; biodiversity;

- developing sustainable agriculture and green land management for restoring

- protection and reforestation;

- protection of waterways, funding of the water desalination facilities.

2. The intensity of the resource use.

- Implementing the green accounting, green balance-sheets for all companies and economic activities with the goal of internalization of externalities. Introducing the polluter pays principle for all substances and activities. Environmental costs to the environment are factored into the expenses of all goods and services.

- Developing the green taxation, reinvestment in renewable energy technologies and climate change impact mitigation.

- Supporting the resource efficiency with the principles of the circular economy.

- Promotion of organic food production.

3. Intellectual capital and innovation.

- Providing the equal quality education, understanding the relevant requirements for the staff, developing vocational training.

- Creating the national and regional economic development strategy supported by government policies, co-ordination, and incentives. Providing the incentives for the young and talented youth. development.

Building the environment that supports and rewards investment in research and

- Limitation the power of monopoly entities.

4. Social cohesion and integration.

- Providing the public health services for all, with additional private health services beyond the basics.

- Integration the law enforcement in local communities and related services to prevent crime.

- $\quad$ Supporting equal opportunities for all genders, races and minority groups. 
- Implementation of the new models of employment and public participation in public services, supporting the robotics and artificial intelligence [12].

5. Governance system. responsibilities.

- Building the efficient governance systems with clear shared obligations and

- Supporting the direct democracy when society could also vote on legislation and policies.

- The equal legal framework and judicial system.

- Developing the financial markets and financial instruments to serve the green economy and green competitiveness.

- Providing the simple equal tax regime for all companies and entities. income taxes.

- Funding the public services (health, education and infrastructure) by progressive

- Efficient and well-maintained transport infrastructure, and other public infrastructure (health, education, recreation).

- Corruption prevention.

- Balancing between the social, environmental and economic interests on the countries and companies' levels.

Conclusion. While summarizing the above mentioned, it is necessary to outline the main issues to be considered for supporting the green competitiveness trends. The important step is the updating the managerial system, facilitation of democracy processes and arrangement the legal equality. Besides, the real producing economy currently should provide money transfer and provision of capital for innovation, production, resource saving and environment protection. Also, the role of the state in the processes of supporting and promoting the green competitiveness processes is significant. The state position in infrastructure-based service provision in ensuring clear efficient management and prevention of corruption in public services should be developed. This research was funded by the grant from the Ministry of Education and Science of Ukraine No 0119U101860 and No 0117 U003932.

\section{References}

1. Hidalgo C., Klinger B., Baraba' si A., Hausmann R. The product space conditions and the development of nations. Science. 2007.317 (5837). P. 482-487. https://doi.org/10.1126/science.1144581

2. Hausmann R., Hidalgo C. The building blocks of economic complexity. Proceedings of the National Academy of Sciences. 2010. 106 (26). P. 10570-10575. https://doi.org/10.1073/pnas.0900943106

3. Fankhauser S., Bowen A., Calel R., Dechezleprêtre A., Grover D. Rydge J., Sato M. Who will win the green race? In search of environmental competitiveness and innovation. Global Environmental Change. 2013. Volume 23. Issue 5. P. 902-913. https://doi.org/10.1016/j.gloenvcha.2013.05.007

4. Sang-Bing Tsai, Riga Saito, Yi-Chuan Lin, Quan Chen, Jie Zhou. Discussing measurement criteria and competitive strategies of green suppliers from a green law perspective. Engineering Manufacture. 2015. Vol. 229 (S1). P. 135-145. https://doi.org/10.1177/0954405414558740

5. Zhang H., Geng Z., Yin R., Zhang W. Regional differences and convergence tendency of green development competitiveness in China. Journal of Cleaner Production. https://doi.org/10.1016/ j.jclepro.2019.119922.

6. Cheng X., Long R., Chen H., Li Q. Coupling coordination degree and spatial dynamic evolution of a regional green competitiveness system - A case study from China. Ecological indicators. 2019. 104. P. 489-500. https://doi.org/10.1016/j.ecolind.2019.04.003

7. Mishenin Ye. V., Chyhryn O. Iu. Zelenyi biznes: suchasni trendy rozvytku ta shliakhy prosuvannia. Enerhoefektyvnist ta vidnovliuvalna enerhetyka v Ukraini: problemy upravlinnia: monohrafiia / za zah. red. d-ra ekon. nauk, prof. I. M. Sotnyk. Sumy, 2019. P. 14-28.

8. Pimonenko T., Chygryn O., Lyulyov O. Green branding as a driver to boost the development of green investment market. Visnyk Cherkaskoho Natsionalnoho universytetu imeni Bohdana Khmelnytskoho. Seriia Ekonomichni nauky. 2019. Vypusk 1. P. 146-153. https://doi.org/10.31651/2076-5843-2019-1-144150 
9. The global sustainable competitiveness index. 2019. Report. 8th edition. Zurich, Seoul.

10. Kamierczak-Piwko L., Ganczewski G. Energy mix of selected EU countries and ecological competitiveness of their economies in the area of production: proceedings of the 33rd International Business Information Management Association Conference. IBIMA: Education Excellence and Innovation Management through Vision. 2019. P. 1911-1930. (In Engl.).

11. Chen S., Liao G., Drakeford B. M., Failler P. The non-linear effect of financial support on energy efficiency: Evidence from China. Sustainability. 2019. 11 (7). https://doi.org/10.3390/su11071959

12. Han M., Lin H., Wang J., Wang Y., Jiang W. Turning corporate environmental ethics into firm performance: The role of green marketing programs. Business Strategy and the Environment. 2019. 28 (6). P. 929-938. https://doi.org/10.1002/bse.2290

\section{Список використаної літератури}

1. Hidalgo C., Klinger B., Baraba' si A., Hausmann R. The product space conditions and the development of nations. Science. 2007.317 (5837). P. 482-487. https://doi.org/10.1126/science.1144581

2. Hausmann R., Hidalgo C. The building blocks of economic complexity. Proceedings of the National Academy of Sciences. 2010. 106 (26). P. 10570-10575. https://doi.org/10.1073/pnas.0900943106

3. Fankhauser S., Bowen A., Calel R., Dechezleprêtre A., Grover D. Rydge J., Sato M. Who will win the green race? In search of environmental competitiveness and innovation. Global Environmental Change. 2013. Volume 23. Issue 5. P. 902-913. https://doi.org/10.1016/j.gloenvcha.2013.05.007

4. Sang-Bing Tsai, Riga Saito, Yi-Chuan Lin, Quan Chen, Jie Zhou. Discussing measurement criteria and competitive strategies of green suppliers from a green law perspective. Engineering Manufacture. 2015. Vol. 229 (S1). P. 135-145. https://doi.org/10.1177/0954405414558740

5. Zhang H., Geng Z., Yin R., Zhang W. Regional differences and convergence tendency of green development competitiveness in China. Journal of Cleaner Production. https://doi.org/10.1016/ j.jclepro.2019.119922.

6. Cheng X., Long R., Chen H., Li Q. Coupling coordination degree and spatial dynamic evolution of a regional green competitiveness system - A case study from China. Ecological indicators. 2019. 104. P. 489-500. https://doi.org/10.1016/j.ecolind.2019.04.003

7. Мішенін С. В., Чигрин О. Ю. Зелений бізнес: сучасні тренди розвитку та шляхи просування. Енергоефективність та відновлювальна енергетика в Україні: проблеми управління: монографія / за заг. ред. д-ра екон. наук, проф. І. М. Сотник. Суми, 2019. С. 14-28.

8. Pimonenko T., Chygryn O., Lyulyov O. Green branding as a driver to boost the development of green investment market. Вісник Черкаського Національного університету імені Богдана Хмельницького. Серія Економічні науки. 2019. Випуск 1. С. 146-153. https://doi.org/10.31651/2076-5843-2019-1-144150

9. The global sustainable competitiveness index. 2019. Report. 8th edition. Zurich, Seoul.

10. Kamierczak-Piwko L., Ganczewski G. Energy mix of selected EU countries and ecological competitiveness of their economies in the area of production: proceedings of the 33rd International Business Information Management Association Conference. IBIMA: Education Excellence and Innovation Management through Vision. 2019. P. 1911-1930. (In Engl.).

11. Chen S., Liao G., Drakeford B. M., Failler P. The non-linear effect of financial support on energy efficiency: Evidence from China. Sustainability. 2019. 11 (7). https://doi.org/10.3390/su11071959

12. Han M., Lin H., Wang J., Wang Y., Jiang W. Turning corporate environmental ethics into firm performance: The role of green marketing programs. Business Strategy and the Environment. 2019. 28 (6). P. 929-938. https://doi.org/10.1002/bse.2290 